\title{
Short communication: Antimicrobial effect of lactoferrin and its amidated and pepsin-digested derivatives against Salmonella Enteritidis and Pseudomonas fluorescens
}

\author{
A. Del Olmo, J. Calzada, and M. Nuñez ${ }^{1}$ \\ Departamento de Tecnología de Alimentos, INIA, Carretera de la Coruña Km 7, Madrid, 28040 Spain
}

\begin{abstract}
The antimicrobial effect of bovine lactoferrin (LF) and its amidated and pepsin-digested derivatives, at concentrations varying from 0.25 to $20 \mathrm{mg} / \mathrm{mL}$, against 3 Salmonella Enteritidis strains and 3 Pseudomonas fluorescens strains was investigated. Lactoferrin showed its maximum antimicrobial effect at $10 \mathrm{mg} / \mathrm{mL}$ against the 3 Salmonella strains, with reductions ranging from 1.3 to $2.0 \mathrm{log}$ units, and the 3 Pseudomonas strains, with reductions ranging from 1.8 to $5.4 \mathrm{log}$ units. In the case of amidated LF, the maximum effect on the 3 Salmonella strains was recorded at $0.25 \mathrm{mg} / \mathrm{mL}$, with reductions in the range of 0.8 to $1.2 \log$ units, whereas it was recorded at $1 \mathrm{mg} / \mathrm{mL}$ for the 3 Pseudomonas strains, with reductions in the range of 4.4 to $6.0 \mathrm{log}$ units. Pepsin-digested LF showed its maximum antimicrobial effect at $1 \mathrm{mg} / \mathrm{mL}$ against the 3 Salmonella strains, with reductions ranging from 2.6 to $3.4 \mathrm{log}$ units, and at $20 \mathrm{mg} / \mathrm{mL}$ against the 3 Pseudomonas strains, with reductions ranging from 4.5 to $5.4 \mathrm{log}$ units. It is worth noting the pronounced effect (reductions exceeding $2.5 \log$ units) of a low $(1 \mathrm{mg} / \mathrm{mL})$ concentration of pepsin-digested LF, which is naturally formed in the gastrointestinal tract, on Salmonella and Pseudomonas strains. A highly significant inverse correlation was found between capsule polysaccharide levels of bacterial strains and their lethality in the presence of different concentrations of amidated lactoferrin.
\end{abstract}

Key words: lactoferrin, derivative, Salmonella, Pseudomonas

Lactoferrin (LF), a single-chain iron-binding glycoprotein of approximately $80 \mathrm{kDa}$, constitutes one of the major antimicrobial systems in milk and various mammalian exocrine secretions (Steijns and van Hooijdonk, 2000). Lactoferricin (LFC) is a basic peptide resulting from pepsin cleavage on the $\mathrm{N}$-terminal domain of LF (Bellamy et al., 1992). Amidated lactoferrin (AMILF)

Received February 9, 2010.

Accepted May 22, 2010.

${ }^{1}$ Corresponding author: nunez@inia.es is obtained by chemical amidation of LF (Pan et al., 2007). Both LF derivatives have been reported to exert a more potent antibacterial activity than the native molecule, because of its lower molecular weight (approximately $3 \mathrm{kDa}$ ) in the case of the LFC molecule (Bellamy et al., 1992), and because of the increase in the net positive charges in the case of the AMILF molecule (Pan et al., 2007).

Inter-species and strain-to-strain variations in the sensitivity of bacteria to LF and its derivatives have been observed. Also, many factors influence the antimicrobial activity of LF and its derivatives, including temperature, water activity, ionic strength, $\mathrm{pH}$, medium composition, presence of cations, microbial population, and stage of growth (Branen and Davidson, 2000; Del Olmo et al., 2008). Independently of the natural activity of LF and some of its derivatives in the digestive tract, these compounds are interesting options for use as natural food preservatives, because of their origin and antimicrobial activity (Payne et al., 1990; Naidu, 2002; Murdock et al., 2007).

We have compared the antimicrobial effect of LF and its amidated and pepsin-digested (PDLF) derivatives against Salmonella Enteritidis, a pathogen that may be found in milk and dairy products, and Pseudomonas fluorescens, a bacterium responsible for the spoilage of milk and dairy products during refrigerated storage. The role of capsule polysaccharide on the resistance of bacterial strains to these antimicrobials was also studied.

Bovine LF, partially (15 to 20\%) iron saturated according to the manufacturer, was obtained from DMV International (Barcelona, Spain). A $250 \mathrm{mg} / \mathrm{mL}$ solution of LF in double-distilled sterile water was used as the stock solution for assays. Amidated lactoferrin was prepared from a $20 \mathrm{mg} / \mathrm{mL}$ LF solution as described by Pan et al. (2007) and then concentrated 10-fold by lyophilization. Pepsin-digested lactoferrin was prepared from a $250 \mathrm{mg} / \mathrm{mL}$ LF solution as described by Dionysius et al. (1993). Stock solutions of the 3 antimicrobials were sterilized by means of $0.20-\mu \mathrm{m}$-pore-size cellulose acetate filters (Millipore, Bedford, MA) and stored at $-20^{\circ} \mathrm{C}$ until use. 
Table 1. Effect of increasing concentrations of lactoferrin (LF), amidated lactoferrin (AMILF), and pepsindigested lactoferrin (PDLF) on the viability of 3 Salmonella Enteritidis strains, after treatment for $1 \mathrm{~h}$ at $30^{\circ} \mathrm{C}$

\begin{tabular}{|c|c|c|c|c|}
\hline \multirow[b]{2}{*}{ Antimicrobial } & \multirow{2}{*}{$\begin{array}{c}\text { Concentration, } \\
\mathrm{mg} / \mathrm{mL}\end{array}$} & \multicolumn{3}{|c|}{ Salmonella Enteritidis count, $\log \mathrm{cfu} / \mathrm{mL}^{1}$} \\
\hline & & CECT 4155 & CECT 4300 & CECT 4396 \\
\hline \multirow[t]{8}{*}{$\overline{L F}$} & 0 & $7.70 \pm 0.02^{\mathrm{e}}$ & $7.41 \pm 0.02^{\mathrm{f}}$ & $7.66 \pm 0.07^{\mathrm{e}}$ \\
\hline & 0.25 & $7.59 \pm 0.03^{\text {de }}$ & $7.18 \pm 0.03^{\mathrm{e}}$ & $7.42 \pm 0.05^{\mathrm{de}}$ \\
\hline & 0.5 & $7.48 \pm 0.05^{\mathrm{cd}}$ & $7.05 \pm 0.02^{\mathrm{d}}$ & $7.30 \pm 0.04^{\mathrm{cd}}$ \\
\hline & 1 & $7.41 \pm 0.06^{\mathrm{c}}$ & $6.93 \pm 0.05^{\mathrm{d}}$ & $7.09 \pm 0.05^{\mathrm{c}}$ \\
\hline & 2 & $7.16 \pm 0.13^{\mathrm{b}}$ & $6.60 \pm 0.04^{\mathrm{c}}$ & $6.20 \pm 0.11^{\mathrm{b}}$ \\
\hline & 5 & $6.48 \pm 0.23^{\mathrm{a}}$ & $6.30 \pm 0.07^{\mathrm{b}}$ & $5.75 \pm 0.11^{\mathrm{a}}$ \\
\hline & 10 & $6.32 \pm 0.33^{\mathrm{a}}$ & $6.14 \pm 0.03^{\mathrm{a}}$ & $5.71 \pm 0.16^{\mathrm{a}}$ \\
\hline & 20 & $6.36 \pm 0.38^{\mathrm{a}}$ & $6.17 \pm 0.02^{\mathrm{a}}$ & $6.07 \pm 0.19^{\mathrm{b}}$ \\
\hline \multirow[t]{8}{*}{ AMILF } & 0 & $7.70 \pm 0.02^{\mathrm{e}}$ & $7.41 \pm 0.02^{\mathrm{e}}$ & $7.66 \pm 0.07^{\mathrm{e}}$ \\
\hline & 0.25 & $6.89 \pm 0.16^{\mathrm{a}}$ & $6.45 \pm 0.05^{\mathrm{a}}$ & $6.50 \pm 0.17^{\mathrm{a}}$ \\
\hline & 0.5 & $6.93 \pm 0.14^{\mathrm{a}}$ & $6.49 \pm 0.06^{\mathrm{ab}}$ & $6.57 \pm 0.17^{\mathrm{ab}}$ \\
\hline & 1 & $7.13 \pm 0.10^{\mathrm{b}}$ & $6.51 \pm 0.08^{\mathrm{ab}}$ & $6.70 \pm 0.15^{\mathrm{b}}$ \\
\hline & 2 & $7.36 \pm 0.05^{\mathrm{c}}$ & $6.58 \pm 0.08^{\mathrm{b}}$ & $6.92 \pm 0.11^{\mathrm{c}}$ \\
\hline & 5 & $7.45 \pm 0.07^{\mathrm{cd}}$ & $6.83 \pm 0.05^{\mathrm{c}}$ & $7.45 \pm 0.05^{\mathrm{d}}$ \\
\hline & 10 & $7.50 \pm 0.06^{\mathrm{d}}$ & $7.17 \pm 0.04^{\mathrm{d}}$ & $7.56 \pm 0.06^{\mathrm{de}}$ \\
\hline & 20 & $7.57 \pm 0.06^{\mathrm{de}}$ & $7.33 \pm 0.03^{\mathrm{e}}$ & $7.63 \pm 0.06^{\mathrm{de}}$ \\
\hline \multirow{8}{*}{ PDLF } & 0 & $7.70 \pm 0.02^{\mathrm{c}}$ & $7.41 \pm 0.02^{\mathrm{f}}$ & $7.66 \pm 0.07^{\mathrm{c}}$ \\
\hline & 0.25 & $5.61 \pm 0.17^{\mathrm{b}}$ & $4.92 \pm 0.05^{\mathrm{c}}$ & $4.59 \pm 0.07^{\mathrm{ab}}$ \\
\hline & 0.5 & $5.21 \pm 0.25^{\mathrm{a}}$ & $4.64 \pm 0.13^{\mathrm{b}}$ & $4.48 \pm 0.09^{\mathrm{ab}}$ \\
\hline & 1 & $5.09 \pm 0.23^{\mathrm{a}}$ & $4.35 \pm 0.08^{\mathrm{a}}$ & $4.24 \pm 0.14^{\mathrm{a}}$ \\
\hline & 2 & $5.14 \pm 0.19^{\mathrm{a}}$ & $4.38 \pm 0.12^{\mathrm{a}}$ & $4.24 \pm 0.12^{\mathrm{a}}$ \\
\hline & 5 & $5.63 \pm 0.18^{\mathrm{b}}$ & $5.45 \pm 0.04^{\mathrm{d}}$ & $4.93 \pm 0.10^{\mathrm{b}}$ \\
\hline & 10 & $5.65 \pm 0.19^{\mathrm{b}}$ & $5.82 \pm 0.05^{\mathrm{e}}$ & $4.88 \pm 0.10^{\mathrm{b}}$ \\
\hline & 20 & $5.61 \pm 0.19^{\mathrm{b}}$ & $5.95 \pm 0.03^{\mathrm{e}}$ & $4.94 \pm 0.09^{\mathrm{b}}$ \\
\hline
\end{tabular}

${ }^{\mathrm{a}-\mathrm{f}}$ For each strain and antimicrobial compound, different superscripts indicate significant $(P<0.05)$ differences between means.

${ }^{1}$ Counts are mean $\pm \operatorname{SEM}(\mathrm{n}=6)$.

Salmonella Enteritidis strains CECT 4155, CECT 4300, and CECT 4396 were obtained from the Spanish Type Culture Collection (CECT, Valencia, Spain). Pseudomonas fluorescens ATCC 948 and ATCC 49838 were obtained from the Belgian Coordinated Collections of Microorganisms (BCCM/LMG, Gent, Belgium). Pseudomonas fluorescens INIA 724 is a strain isolated from ovine raw milk at our laboratory. A $50-\mu \mathrm{L}$ culture aliquot of each microorganism was added to $9 \mathrm{~mL}$ of tryptic soy broth (Biolife, Milano, Italy) for Salmonella or tryptic soy yeast extract broth (Biolife) for Pseudomonas, incubated for $24 \mathrm{~h}$ at $37^{\circ} \mathrm{C}$ or $25^{\circ} \mathrm{C}$, respectively, and stored at $-30^{\circ} \mathrm{C}$ after adding $15 \%$ glycerol for use as stock cultures.

Salmonella strains were inoculated into tryptic soy broth and incubated at $37^{\circ} \mathrm{C}$ for $18 \mathrm{~h}$, and Pseudomonas strains in tryptic soy yeast extract broth and incubated at $25^{\circ} \mathrm{C}$ for $18 \mathrm{~h}$. The grown cultures were diluted $(1: 100)$ in $0.1 \%$ (wt/vol) peptone aqueous solution (Biolife), centrifuged at $6,000 \times g$ for 15 min at $25^{\circ} \mathrm{C}$, and the pellet was resuspended in Tris- $\mathrm{HCl}$ buffer $(50$ $\mathrm{m} M, \mathrm{pH} 7.0$ ) to approximately $10^{7} \mathrm{cfu} / \mathrm{mL}$. Aliquots of resuspended cells were treated with LF and LF derivatives at different concentrations and incubated for $1 \mathrm{~h}$ at $30^{\circ} \mathrm{C}$. Control samples contained no added antimi- crobial. After incubation, samples were centrifuged at $6,000 \times g$ for $15 \mathrm{~min}$ at $25^{\circ} \mathrm{C}$ and resuspended in the same volume of Tris buffer to eliminate antimicrobials, serially diluted in $0.1 \%$ (wt/vol) peptone solution, plated on tryptic soy yeast extract agar, and incubated for $24 \mathrm{~h}$ at $37^{\circ} \mathrm{C}$ for Salmonella strains or at $30^{\circ} \mathrm{C}$ for Pseudomonas strains.

Cell-associated capsule polysaccharide (CPS) was purified by a modified phenol-extraction method (Campos et al., 2004). The sugar content of the purified CPS was determined as described by Dubois et al. (1956) and referred to a D-glucose standard. Additionally, bacterial counts were determined in tryptic soy yeast extract agar. The amount of CPS was expressed as micrograms of CPS $/ 10^{8}$ cfu or as micrograms of CPS $/ \mathrm{mL}$ present in the antimicrobial assay.

Experiments were performed in triplicate, with microbiological determinations in duplicate. Results were submitted to a 2-way ANOVA using program Statview, version 5.0 (SAS Institute, Cary, NC). The TukeyKramer test was used for the comparison of means, with significance assigned at $P<0.05$. The relationship between the bactericidal effect and the amount of CPS present in assays was estimated by simple regression analysis. 
Table 2. Effect of increasing concentrations of lactoferrin (LF), amidated lactoferrin (AMILF), and pepsindigested lactoferrin (PDLF) on the viability of 3 Pseudomonas fluorescens strains, after treatment for $1 \mathrm{~h}$ at $30^{\circ} \mathrm{C}$

\begin{tabular}{|c|c|c|c|c|}
\hline \multirow[b]{2}{*}{ Antimicrobial } & \multirow{2}{*}{$\begin{array}{c}\text { Concentration, } \\
\mathrm{mg} / \mathrm{mL}\end{array}$} & \multicolumn{3}{|c|}{ P. fluorescens count, $\log \mathrm{cfu} / \mathrm{mL}^{1}$} \\
\hline & & ATCC 948 & ATCC 49838 & INIA 724 \\
\hline \multirow[t]{8}{*}{$\mathrm{LF}$} & 0 & $7.39 \pm 0.07^{\mathrm{g}}$ & $7.67 \pm 0.03^{\mathrm{h}}$ & $7.37 \pm 0.21^{\mathrm{f}}$ \\
\hline & 0.25 & $6.34 \pm 0.07^{\mathrm{f}}$ & $7.33 \pm 0.15^{\mathrm{g}}$ & $7.13 \pm 0.17^{\mathrm{e}}$ \\
\hline & 0.5 & $5.80 \pm 0.11^{\mathrm{e}}$ & $6.79 \pm 0.23^{\mathrm{f}}$ & $6.83 \pm 0.22^{\mathrm{d}}$ \\
\hline & 1 & $4.80 \pm 0.15^{\mathrm{d}}$ & $5.86 \pm 0.19^{\mathrm{e}}$ & $6.58 \pm 0.28^{\mathrm{c}}$ \\
\hline & 2 & $3.21 \pm 0.14^{\mathrm{c}}$ & $4.86 \pm 0.12^{\mathrm{d}}$ & $5.99 \pm 0.26^{\mathrm{b}}$ \\
\hline & 5 & $2.50 \pm 0.19^{\mathrm{b}}$ & $4.26 \pm 0.13^{\mathrm{c}}$ & $5.68 \pm 0.30^{\mathrm{a}}$ \\
\hline & 10 & $2.02 \pm 0.23^{\mathrm{a}}$ & $3.92 \pm 0.14^{\mathrm{b}}$ & $5.57 \pm 0.26^{\mathrm{a}}$ \\
\hline & 20 & $2.06 \pm 0.23^{\mathrm{a}}$ & $3.69 \pm 0.15^{\mathrm{a}}$ & $5.59 \pm 0.26^{\mathrm{a}}$ \\
\hline \multirow[t]{8}{*}{ AMILF } & 0 & $7.39 \pm 0.07^{\mathrm{f}}$ & $7.67 \pm 0.03^{\mathrm{d}}$ & $7.37 \pm 0.21^{\mathrm{e}}$ \\
\hline & 0.25 & $3.64 \pm 0.13^{\mathrm{cd}}$ & $4.76 \pm 0.29^{\mathrm{c}}$ & $2.20 \pm 0.30^{\mathrm{b}}$ \\
\hline & 0.5 & $2.12 \pm 0.09^{\mathrm{b}}$ & $4.52 \pm 0.27^{\mathrm{c}}$ & $1.51 \pm 0.59^{\mathrm{a}}$ \\
\hline & 1 & $1.70 \pm 0.12^{\mathrm{a}}$ & $3.28 \pm 0.41^{\mathrm{a}}$ & $1.40 \pm 0.49^{\mathrm{a}}$ \\
\hline & 2 & $2.43 \pm 0.26^{\mathrm{b}}$ & $3.76 \pm 0.30^{\mathrm{b}}$ & $2.28 \pm 0.23^{\mathrm{b}}$ \\
\hline & 5 & $3.38 \pm 0.12^{\mathrm{c}}$ & $3.75 \pm 0.29^{\mathrm{b}}$ & $3.03 \pm 0.24^{\mathrm{c}}$ \\
\hline & 10 & $3.88 \pm 0.19^{\mathrm{de}}$ & $3.70 \pm 0.28^{\mathrm{b}}$ & $4.22 \pm 0.31^{\mathrm{d}}$ \\
\hline & 20 & $4.02 \pm 0.09^{\mathrm{e}}$ & $3.72 \pm 0.28^{\mathrm{b}}$ & $4.53 \pm 0.32^{\mathrm{d}}$ \\
\hline \multirow{8}{*}{ PDLF } & 0 & $7.39 \pm 0.07^{\mathrm{g}}$ & $7.67 \pm 0.03^{\mathrm{g}}$ & $7.37 \pm 0.21^{\mathrm{g}}$ \\
\hline & 0.25 & $5.33 \pm 0.07^{\mathrm{f}}$ & $6.53 \pm 0.21^{\mathrm{f}}$ & $6.92 \pm 0.20^{\mathrm{f}}$ \\
\hline & 0.5 & $4.98 \pm 0.21^{\mathrm{e}}$ & $6.01 \pm 0.16^{\mathrm{e}}$ & $6.67 \pm 0.33^{\mathrm{e}}$ \\
\hline & 1 & $3.88 \pm 0.09^{\mathrm{d}}$ & $4.46 \pm 0.08^{\mathrm{d}}$ & $4.95 \pm 0.32^{\mathrm{d}}$ \\
\hline & 2 & $3.16 \pm 0.11^{\mathrm{c}}$ & $3.65 \pm 0.06^{\mathrm{c}}$ & $3.49 \pm 0.35^{\mathrm{c}}$ \\
\hline & 5 & $2.98 \pm 0.09^{\mathrm{c}}$ & $3.44 \pm 0.04^{\mathrm{bc}}$ & $3.36 \pm 0.30^{\mathrm{c}}$ \\
\hline & 10 & $2.55 \pm 0.19^{\mathrm{b}}$ & $3.35 \pm 0.07^{\mathrm{ab}}$ & $3.17 \pm 0.26^{\mathrm{b}}$ \\
\hline & 20 & $2.02 \pm 0.25^{\mathrm{a}}$ & $3.13 \pm 0.15^{\mathrm{a}}$ & $2.92 \pm 0.24^{\mathrm{a}}$ \\
\hline
\end{tabular}

${ }^{\mathrm{a} h}$ For each strain and antimicrobial compound, different superscripts indicate significant $(P<0.05)$ differences between means.

${ }^{1}$ Counts are mean \pm SEM $(\mathrm{n}=6)$.

A similar behavior in response to increasing concentrations of antimicrobials was found for the 3 tested Salmonella strains (Table 1). For the 3 strains, the maximum effect of $\mathrm{LF}$ was recorded at $10 \mathrm{mg} / \mathrm{mL}$, with reductions in bacterial counts ranging from $1.27 \mathrm{log}$ $\mathrm{cfu} / \mathrm{mL}$ for strain CECT 4300 to $1.95 \log \mathrm{cfu} / \mathrm{mL}$ for strain CECT 4396. Amidated LF showed its maximum effect at the lowest tested concentration $(0.25 \mathrm{mg} / \mathrm{mL})$, for which reductions ranged from $0.81 \log \mathrm{cfu} / \mathrm{mL}$ for strain CECT 4155 to $1.16 \log \mathrm{cfu} / \mathrm{mL}$ for strain CECT 4396. Pepsin-digested LF exhibited the maximum effect at $1 \mathrm{mg} / \mathrm{mL}$, with reductions ranging from $2.61 \log \mathrm{cfu} /$
$\mathrm{mL}$ for strain CECT 4155 to $3.42 \log \mathrm{cfu} / \mathrm{mL}$ for strain CECT 4396. Interestingly, the most pronounced effect on Salmonella strains was recorded for PDLF, which is naturally formed in the gastrointestinal tract by the action of digestive enzymes.

The 3 P. fluorescens strains also showed a common pattern in response to increasing concentrations of LF and its derivatives (Table 2). Lactoferrin exhibited its maximum antimicrobial effect at $10 \mathrm{mg} / \mathrm{mL}$, with reductions ranging from $1.80 \log \mathrm{cfu} / \mathrm{mL}$ for strain INIA 724 to $5.37 \log \mathrm{cfu} / \mathrm{mL}$ for strain ATCC 948. The highest effect of AMILF was reached at only $1 \mathrm{mg} / \mathrm{mL}$,

Table 3. Capsule polysaccharide (CPS) produced by Salmonella Enteritidis and Pseudomonas fluorescens strains

\begin{tabular}{lcc}
\hline Strain & $\begin{array}{c}\mathrm{CPS} / 10^{8} \\
\mathrm{cfu}, \mu \mathrm{g}\end{array}$ & $\begin{array}{c}\text { CPS/mL in the } \\
\text { antimicrobial assay, } \mu \mathrm{g}\end{array}$ \\
\hline Salmonella Enteritidis CECT 4155 & $5.01 \pm 0.75^{\mathrm{bc}}$ & $2.51 \pm 0.37^{\mathrm{bc}}$ \\
Salmonella Enteritidis CECT 4300 & $3.52 \pm 0.84^{\mathrm{abc}}$ & $0.90 \pm 0.22^{\mathrm{a}}$ \\
Salmonella Enteritidis CECT 4396 & $6.18 \pm 1.49^{\mathrm{c}}$ & $2.82 \pm 0.68^{\mathrm{c}}$ \\
Pseudomonas fluorescens ATCC 948 & $3.46 \pm 0.58^{\mathrm{abc}}$ & $0.85 \pm 0.14^{\mathrm{a}}$ \\
Pseudomonas fluorescens ATCC 49838 & $2.35 \pm 0.71^{\mathrm{ab}}$ & $1.10 \pm 0.33^{\mathrm{ab}}$ \\
Pseudomonas fluorescens INIA 724 & $0.56 \pm 0.03^{\mathrm{a}}$ & $0.13 \pm 0.01^{\mathrm{a}}$ \\
\hline${ }^{\mathrm{a}-\mathrm{c}}$ Different superscripts within each column indicate significant $(P<0.05)$ differences between strains. \\
${ }^{1}$ Results are mean \pm SEM $(\mathrm{n}=3)$.
\end{tabular}


with reductions ranging from $4.39 \mathrm{log} \mathrm{cfu} / \mathrm{mL}$ for strain ATCC 49838 to $5.97 \log \mathrm{cfu} / \mathrm{mL}$ for strain INIA 724 . On the other hand, $20 \mathrm{mg} / \mathrm{mL}$ of PDLF were needed for its maximum effect, with reductions ranging from 4.45 $\log \mathrm{cfu} / \mathrm{mL}$ for strain INIA 724 to $5.37 \mathrm{log} \mathrm{cfu} / \mathrm{mL}$ for strain ATCC 948. As recorded for Salmonella strains, it is worth noting the pronounced effect of PDLF at a low concentration $(1 \mathrm{mg} / \mathrm{mL})$ on Pseudomonas strains.

Salmonella strains produced higher concentrations of CPS (expressed as D-glucose) than Pseudomonas strains (Table 3), with values ranging from 3.52 to $6.18 \mu \mathrm{g} / 10^{8} \mathrm{cfu}$ for Salmonella, and from 0.56 to 3.46 $\mu \mathrm{g} / 10^{8} \mathrm{cfu}$ for Pseudomonas. Concentrations of CPS actually present in assays ranged from 0.90 to $2.82 \mu \mathrm{g} /$ $\mathrm{mL}$ for Salmonella and from 0.13 to $1.10 \mu \mathrm{g} / \mathrm{mL}$ for Pseudomonas. In the case of LF and PDLF, there was no significant relationship between CPS concentration in assays and the effect of antimicrobials. However, a highly significant $\left(P<0.001 ; \mathrm{r}^{2}=0.516\right)$ inverse relationship between AMILF antimicrobial effect and CPS concentration was recorded, which followed the equation $y=4.455-1.479 x(y=$ reduction in $\log \mathrm{cfu} / \mathrm{mL}$; $x=$ CPS concentration in $\mu \mathrm{g} / \mathrm{mL})$.

Lactoferrin and its derivatives have been reported to directly interact, because of their positive charges, with the anionic LPS (probably with the lipid A part of LPS) of gram-negative bacteria or with the negatively charged teichoic acids of gram-positive bacteria, causing the withdrawal of LPS or teichoic acids, and destabilizing and damaging membranes (Ellison and Giehl, 1991; Appelmelk et al., 1994). In our study, we observed a higher antimicrobial effect of LF and its derivatives on Pseudomonas than on Salmonella. A factor that might be involved in the bacterial resistance to LF and its derivatives is the bacterial capsule. Capsule polysaccharides are highly hydrated molecules composed of repeating monosaccharide or oligosaccharide units bound by glycosidic linkages (Roberts, 1996). Most CPS are hydrophilic, confer a negative charge on the bacterial surface, and could act as a protective shield or trap antimicrobials preventing them from reaching membrane targets (Llobet et al., 2008). The higher amounts of CPS produced by Salmonella strains than by Pseudomonas strains (Table 3) could be related to their higher resistance to LF and its derivatives.

Lactoferrin exerts its activity by binding to lipid A (Appelmelk et al., 1994) or to membrane proteins such as porins (Kalmar and Arnold, 1988) in a saturable manner. This would be in agreement with our results for LF, which reached its maximum antimicrobial effect at $10 \mathrm{mg} / \mathrm{mL}$. However, AMILF on Pseudomonas and PDLF on Salmonella showed unusual concentrationdependent effects with maximum activity at just $1 \mathrm{mg} /$
mL. Moreover, AMILF showed its maximum activity against Salmonella strains at the lowest tested concentration, $0.25 \mathrm{mg} / \mathrm{mL}$. Electrostatic repulsions between molecules of the antimicrobials due to their high positive net charges might be partly responsible for these results.

The antimicrobial effect recorded in the present work for a low $(1 \mathrm{mg} / \mathrm{mL})$ concentration of PDLF, which is naturally formed in the gastrointestinal tract, on Salmonella and Pseudomonas strains is worth noting. On the other hand, the antimicrobial activity of LF and its derivatives seems promising with respect to the use of such agents as food preservatives.

\section{ACKNOWLEDGMENTS}

Financial support from projects S-0505/AGR/0314 (Comunidad de Madrid), CSD 2007-00016 (Consolider), and AGL 2007-65235-C02-01 (MICINN) is acknowledged.

\section{REFERENCES}

Appelmelk, B. J., Y. Q. An, M. Geerts, B. G. Thiijs, H. A. de Boer, D. M. Macharen, J. De Graaff, and J. H. Nuijens. 1994. Lactoferrin is a lipid A-binding protein. Infect. Immun. 62:2628-2632.

Bellamy, W., M. Takase, H. Wakabayashi, K. Kawase, and M. Tomita. 1992. Antibacterial spectrum of lactoferricin B, a potent bactericidal peptide derived from the N-terminal region of bovine lactoferrin. J. Appl. Bacteriol. 73:472-479.

Branen, J., and P. M. Davidson. 2000. Activity of hydrolysed lactoferrin against food borne pathogenic bacteria in growth media: The effect of EDTA. Lett. Appl. Microbiol. 30:233-237.

Campos, M. A., M. A. Vargas, V. Regueiro, C. M. Llompart, S. Alberti, and J. A. Bengoechea. 2004. Capsule polysaccharide mediates bacterial resistance to antimicrobial peptides. Infect. Immun. 72:7107-7114.

Del Olmo, A., P. Morales, and M. Nuñez. 2008. Bactericidal effect of lactoferrin and its amidated and pepsin-digested derivatives on Pseudomonas fluorescens: Influence of environmental and physiological factors. J. Food Prot. 71:2468-2474.

Dionysius, D. A., P. A. Grieve, and J. M. Milne. 1993. Forms of lactoferrin: Their antibacterial effect on enterotoxigenic Escherichia coli. J. Dairy Sci. 76:2597-2606.

Dubois, M., K. A. Gilles, J. K. Hamilton, P. A. Bebers, and F. Smith. 1956. Colorimetric method for determination of sugars and related substances. Anal. Chem. 28:350-356.

Ellison, R. T. III, and T. J. Giehl. 1991. Killing of gram-negative bacteria by lactoferrin and lysozyme. J. Clin. Invest. 88:10801091.

Kalmar, J. R., and R. R. Arnold. 1988. Killing of Actinobacillus actinomycetemcomitans by human lactoferrin. Infect. Immun. $56: 2552-2557$

Llobet, E., J. M. Tomás, and J. A. Bengoechea. 2008. Capsule polysaccharide is a bacterial decoy for antimicrobial peptides. Microbiology 154:3877-3886.

Murdock, C. A., J. Cleveland, K. R. Matthews, and M. L. Chikindas, 2007. The synergistic effect of nisin and lactoferrin on the inhibition of Listeria monocytogenes and Escherichia coli O157:H7. Lett. Appl. Microbiol. 44:255-261.

Naidu, A. S. 2002. Activated lactoferrin: A new approach to meat safety. Food Technol. 56:40-45. 
Pan, Y., B. Shiell, J. Wan, M. J. Coventry, H. Roginski, A. Lee, and W. P. Michalski. 2007. The molecular characterisation and antimicrobial activity of amidated bovine lactoferrin. Int. Dairy J. $17: 606-616$.

Payne, K. D., P. M. Davidson, S. P. Oliver, and G. L. Christen. 1990. Influence of bovine lactoferrin on the growth of Listeria monocytogenes. J. Food Prot. 53:468-472.
Roberts, I. S. 1996. The biochemistry and genetics of capsular polysaccharide production in bacteria. Annu. Rev. Microbiol. 50:285-315.

Steijns, J. M., and A. C. M. van Hooijdonk. 2000. Occurrence, structure, biochemical properties and technological characteristics of lactoferrin. Br. J. Nutr. 84:S11-S17. 